\title{
History of primate behavioural and ecological field research at the German Primate Center
}

\author{
E. W. Heymann ${ }^{1}$ and J. U. Ganzhorn ${ }^{2}$ \\ ${ }^{1}$ Verhaltensökologie \& Soziobiologie, Deutsches Primatenzentrum, Kellnerweg 4, 37077 Göttingen, Germany \\ ${ }^{2}$ Zoologisches Institut, Universität Hamburg, Martin-Luther-King Platz 3, 20146 Hamburg, Germany
}

Correspondence to: E. W. Heymann (eheyman@gwdg.de)

Received: 18 May 2015 - Revised: 13 August 2015 - Accepted: 24 August 2015 - Published: 4 September 2015

\begin{abstract}
This paper describes the background of the first behavioural and ecological field studies on primates conducted by German primatologists in the late 1960s and early 1970s. Field research by scientists from DPZ started in the middle 1980s at a time when this was not yet considered a major task for DPZ. Establishment of field research became possible due to recommendations from institutional and departmental evaluations and the formation of a working group "Ethology and Ecology", which was later transformed into a department in the 1990s. Since then, field research has gained momentum, and has become part of the research program of other DPZ departments. The DPZ is now unique, as it runs field sites in all major areas of primate distribution. The foresight and support of Hans-Jürg Kuhn during his period as scientific director was seminal and essential for the evolution of primate field research at DPZ.
\end{abstract}

\section{Prologue}

This article is not a research paper. Rather it is a paper that expresses our personal view of how field research on primate behaviour and ecology "evolved" at the Deutsches Primatenzentrum (DPZ) and how DPZ's founding director Prof. Dr. Hans-Jürg Kuhn contributed to this development. We try to put this account into the perspective of earlier primatological field research in Germany and therefore also shortly present information on German primatological field researchers from the 1960s and 1970s. We do not pretend that this information is exhaustive and apologize for any omission we may have committed. Our view on the history of primatological field research at the DPZ is tightly linked to our personal history as field researchers. The problems we encountered and the experiences we made - particularly at the beginning of our career - are likely to be quite different from what young students and scientists are confronted with today. Some aspects were easier, some were more complicated. Our hope is that this paper can reconcile the young generation of primatological field researchers with the problems they are confronted with, and that they recognize how conditions particularly for getting started - have changed over the last decades.

\section{Early primate field research}

Primatological field research in the first half of the 20th century mainly consisted of the collection of wild primates to obtain material for comparative morphological and taxonomic studies, sometimes complemented by observations on the natural history of the collected species (e.g. Krieg 1930). The title of a biography of the German-Swiss physical anthropologist and primatologist Adolph Hans Schultz by Chaoui (2004) - Mit Messzirkel und Schrotflinte (With Calliper and Shotgun - vividly illustrates this approach. Notable exceptions were behavioural studies by Nissen (1932) on chimpanzees and Carpenter $(1934,1935)$ on howler and spider monkeys, respectively.

The "modern period of primate studies" (DeVore, 1965a, p. vii) began more or less in the middle of the 1950s. The hypothesis of the North-American anthropologist Sherwood L. Washburn that social organization represents an adaptation to ecological conditions initiated a wave of field studies of primates in their natural habitat (Kummer, 1975; Washburn et al., 1965). A major aim was to achieve a better understanding of the evolution of human behaviour, particularly social behaviour. Two edited volumes by DeVore (1965b) and Jay (1968) summarized the results of these 
studies. Notably, not a single contribution came from German primatologists, despite a strong primatological tradition in Germany. However, research on primates in Germany mainly focused on comparative morphology, as evidenced by the monumental Primatologia - Handbuch der Primatenkunde (Handbook of Primatology), edited by the anatomists Helmut Hofer and Dietrich Starck, together with Adolph Hans Schultz (e.g. Hofer et al., 1956).

\section{Behavioural and ecological field studies by German scientists in the 1960 s and 1970 s}

The first German biologist to conduct a behavioural and ecological field study was Christian Vogel. In 1968, he spent 3 months in the Kumaon hills and in Rajasthan (India) to investigate wild Hanuman langurs, Semnopithecus entellus, under contrasting ecological conditions (Vogel, 1977). Vogel was accompanied by psychology students Inge Weber and Horst Krüger (Vogel, 1969a) who did much of the technical preparation of the expedition and contributed to data collection (Weber and Vogel, 1970). Vogel's principal background was palaeoanthropology and primate morphology (e.g. Vogel, 1961), but he was also aware of the relevance of behavioural research on primates for understanding the evolution of human adaptations (Vogel, 1966). Conceptually, this first study was located within the attempts to understand the adaptive value of social behaviour and organization, although, as Vogel (1977, p. 3) emphasized, "We therefore did not aim to address precise research questions that we had previously specified, nor to critically examine certain preconceived hypotheses" 1 .

After Vogel had become the Chair of Anthropology at the Universität Göttingen in 1972, field research on langurs in Jodhpur (Rajasthan) was continued by students and scientists such as Hartmut Loch, Paul Winkler, Volker Sommer and Carola Borries (e.g. Borries, 1988; Sommer, 1987; Winkler et al., 1984). In conjunction with research by Indian primatologists, these studies created long-term demographic and lifehistory data for langurs in Jodhpur, and important insights into social structure and proximate and ultimate causes of infanticide. In 1990 field research on langurs by Vogel's research group moved from Jodhpur to Ramnagar in Nepal, to broaden the comparative scope and to continue research in an ecologically (setting different from Jodhpur (e.g. Koenig et al., 1997; Nikolei and Borries, 1997).

The background of three other primatological field studies by German scientists that took place in the early 1970s was quite different from the langur studies. Studies by Michael J. Casimir and Hans-Jörg Schlichte were embedded in the research program "Ecology of Tropical Forests" and had an ecological focus, while the study by Carsten

\footnotetext{
1"Es ging uns also nicht um eine vorher präzisierte spezielle Fragestellung und um die kritische Überprüfung bestimmter vorgefaßter Hypothesen".
}

Niemitz employed a combined functional-morphological and ethological approach. The program "Ecology of Tropical Forests" had been initiated by Peter Kunkel and was funded by the Volkswagen Stiftung. Geographically it was located in the Kahuzi-Biega region, former Zaïre. After his dissertation, Michael J. Casimir was determined to study fish in Lake Kivu, but for various reasons the project could not be executed. When the research program "Ecology of Tropical Forests" searched for a scientist to work on mountain gorillas, Gorilla beringei, Casimir got involved and spent 15 months in 1971-1972 to explore different aspects of the ecology and behaviour of these highly endangered primates (Casimir, 1975, 1979; Casimir and Butenandt, 1973). He then left primatology and became an ethnologist.

The second primatological project within the "Ecology of Tropical Forests" program was conducted by HansJörg Schlichte who spent 5 months in 1972 at Kahuzi-Biega to study the ecology of blue monkeys, Cercopithecus mitis stuhlmannni (Schlichte, 1975, 1978a). He had become attracted to the research program due to a link between the supervisor of his dissertation on the orientation of homing pigeons, Klaus Schmidt-Koenig, and the program coordinator Peter Kunkel. Due to political instability and uproar in the region, the entire program had to be dismissed (Kunkel, 2013); researchers that remained with the program transferred their projects to Guatemala. Here, at Tikal, Schlichte conducted a 4-month study in 1974-1975 on the ecology of black howler monkeys, Alouatta pigra (Schlichte, 1978b). Schlichte's project terminated with the end of the "Ecology of Tropical Forests" program in 1976.

The projects by Casimir and Schlichte were loosely linked through the research program "Ecology of Tropical Forests" and both were in contact with Christian Vogel at some point of time: Casimir to seek advice on the systematic position of his study population (Casimir, 1974) and Schlichte during an intermezzo at the Zoological Institute of the Universität Göttingen.

Field research by Carsten Niemitz had still other and very different antecedents. Niemitz became attracted to primatology through lectures by the later supervisor of his doctoral thesis, Heinrich Sprankel, by then researcher in the Primatology Department of the Max-Planck-Institut (MPI) für Hirnforschung in Frankfurt and lecturer at the Universität Giessen. Niemitz approached Sprankel with the idea to conduct field research on night monkeys at the Universität Giessen's biological field station in Santa Marta, Colombia. Due to organizational and bureaucratic hurdles, this turned out to be impossible. While Niemitz was reporting about these problems to Sprankel, Barbara Harrisson - known for her early research and conservation activities on orangutans and tarsiers in Sarawak (e.g. Harrisson, 1960, 1961, 1963) was working in the same office at the MPI and intervened by suggesting Field research on tarsiers as an alternative. After the approval of a grant from the Deutsche Forschungsgemeinschaft (DFG), Niemitz set out for the first intensive 
and systematic field study of any tarsier species (Tarsius bancanus borneanus) from 1971-1973, in which he combined behavioural, functional morphological and ecological approaches (Niemitz, 1973; see also Niemitz, 2010, for a detailed account of his field research). After a post-doctoral period at the Anatomical Institute of the Universität Göttingen (with Hans-Jürg Kuhn), Niemitz became a professor for human biology at the Freie Universität Berlin from where he continued and extended field his research on tarsiers and other primate taxa (e.g. Engelhardt et al., 2004, 2006; Matthews et al., 1998; Niemitz, 1984; Niemitz et al., 1991).

\section{Field research at DPZ}

\subsection{The beginnings}

The Deutsches Primatenzentrum was founded in 1977 as a research and service institute (see Schwibbe, 2015). Behavioural and ecological (field) research was not identified as part of DPZ's mission (Kuhn, 1970). Hans-Jürg Kuhn, DPZ's founding director, had done mammalogical and anatomical field research himself in the 1960s (e.g. Kuhn, 1965, 1972). His scientific interests and perspectives were and are much broader. Soon after DPZ's primate housing facilities had become functional, a working group for ethology could be established.

Activities by Kuhn were ultimately seminal for the initiation of DPZ field research. In November 1980, he attended the "Workshop on Management and Production of Primates in their Indigenous Countries", organized by the PanAmerican Health Organization (PAHO) in Iquitos, Peru. During this workshop, Kuhn established first contacts with the Centro de Reproducción y Conservación de Primates (CRCP), the Peruvian primate centre in Iquitos. He also explored the options for conducting primate field research in northeastern Peru (Kuhn, 1980). Subsequently, PAHO and DPZ entered a contract for scientific cooperation. In the framework of this contract, Eckhard W. Heymann (EWH) stayed at CRCP between October 1982 and March 1983 to study vocal and olfactory communication of tamarins, Saguinus mystax and Saguinus fuscicollis, in CRCP's outdoor facility. During this time, the idea for a field study on these callitrichids was born. After conclusion of his dissertation, a grant from the DFG enabled EWH to start the first DPZ field research project in June 1985 (Fig. 1). The original plan to work at the study site where Marleni Ramirez, Marilyn Norconk and Paul Garber had been conducting research between 1981 and 1984 (e.g. Garber, 1988; Norconk, 1990; Ramirez, 1989) was changed when EWH met the Peruvian biologist Rogerio Castro at the CRCP in Iquitos. Castro had established a new field site on the right bank of Quebrada Blanco, where tamarins were much more habituated than at the other site (Castro, 1991) which allowed observations of unprecedented detail. Furthermore, Castro's site was with equipped a regu-

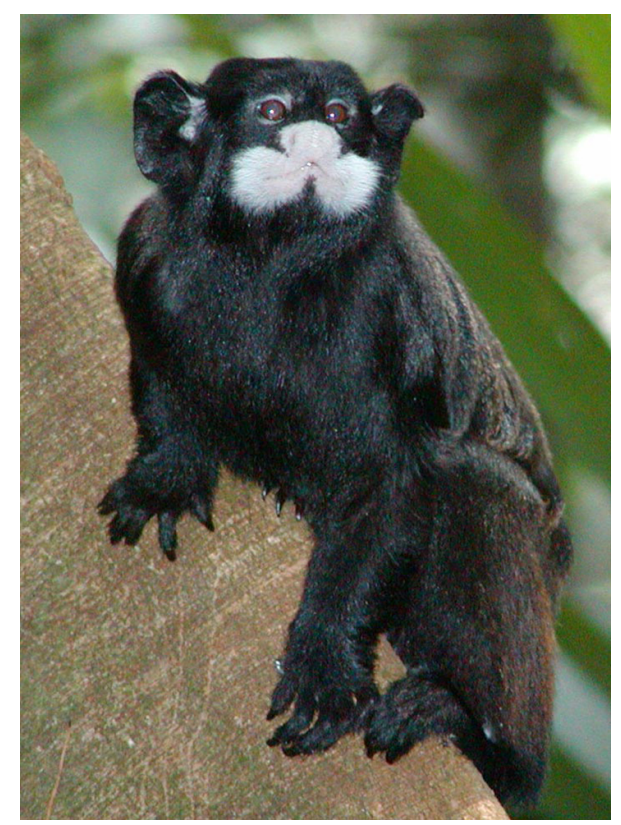

Figure 1. Moustached tamarins, Saguinus mystax, were the focal species of the first DPZ field study in 1985-1986 (Photo (C)Julia Diegmann and Eckhard W. Heymann).

lar grid of trails running north-south and west-east at $100 \mathrm{~m}$ distances, which strongly facilitated field work.

During the 13-month field study, EWH was joined by Ursula Bartecki. They conducted the first systematic studies of scent marking behaviour in wild callitrichids (Bartecki and Heymann, 1990; Heymann 1998, 2000). Observations of red uakaris, Cacajao calvus ucayalii, (Bartecki and Heymann, 1987) led to a report (Bartecki et al., 1986) that initiated the process for establishing a community reserve in the area, now known as "Area de Conservación Comunal-Regional Tamshiyacu-Tahuayo" (Wikipedia, 2015).

A major problem with these first DPZ field studies was the fact that they had to start almost from scratch. There was nobody at DPZ with experience in primate field research in a tropical rainforest. And as these were pre-internet and pre-email times, it was not as easy to find out about and to get in touch with other field researchers as it is today. Nevertheless, the field study could be completed successfully, which subsequently allowed EWH to return to Peru for a second study in 1990.

\subsection{Field work at DPZ gains momentum}

A crucial event for the further development of behavioural and ecological field research at the DPZ was the recommendation in the report of the evaluation by the Wissenschaftsrat (The German Council of Science and Humanities) (1991, p. 32): “... the Wissenschaftsrat considers a sustainable 


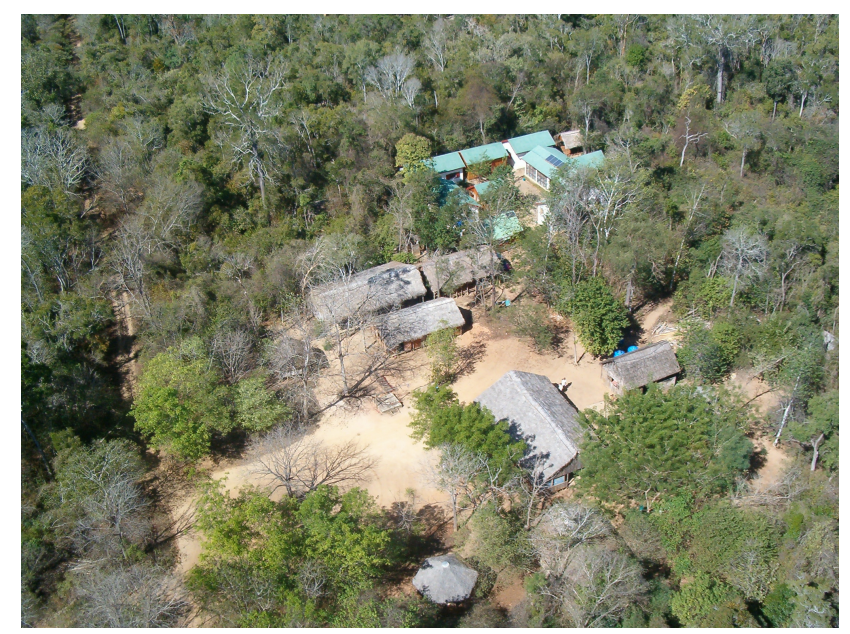

Figure 2. Aerial view of the Kirindy field station. Operated by DPZ since 1993, it is now the largest DPZ field station (Photo: Deutsches Primatenzentrum GmbH).

intensification as essential that would allow to conduct larger field research projects".

Subsequently, plans for the intensification of field research were pushed by Hans-Jörg Kuhn together with Gerhard Neuweiler, by then chairman of DPZ's scientific advisory board. A symposium held at DPZ in August 1992 and supported by the Thyssen Foundation explored perspectives and options for building up a pertinent group at DPZ. Finally, in 1993 the Arbeitsgruppe Verhaltensforschung/Ökologie (Working Group Ethology/Ecology) was established under the directorship of Jörg U. Ganzhorn (JUG).

JUG had come to primatological field research because a planned doctoral project on African antelopes had not come through. Then his supervisor Klaus Schmidt-Koenig used a personal link with Peter Klopfer and Elwyn Simons to initiate JUG's research on lemurs at the Duke University Primate Center. Coincidentally, and after more than a decade of isolation from western countries, Madagascar re-opened its boundaries for western researchers, and JUG was one of the first to be allowed to do field research in Madagascar after the transition from being a French colony to an independent country. By then, working conditions were challenging, but due to the long research vacuum of the country, basically any observation was new and received more attention than similar achievements in other parts of the world, thus nicely illustrating the pros and cons of early primatological field research (e.g. Ganzhorn, 1987, 1989; Ganzhorn et al., 1985). After having worked at various sites in Madagascar, JUG, by then assistant of K. Schmidt-Koenig at the Universität Tübingen, eventually started to collaborate with the Swiss Development Agency in 1987 to establish a permanent research

2“... hält der Wissenschaftsrat eine nachhaltige Verstärkung für erforderlich, die es erlauben würde, auch größere Projekte der Feldforschung ... durchzuführen “ station in the Forêt de Kirindy (Kirindy/CFPF) with the goal to combine conservation and evolutionary research in one of Madagascar's centres of endemism (Ganzhorn, 1991; Ganzhorn et al., 1990). During the first few years, the station had been funded by the Fritz Thyssen Foundation and DFG. When JUG became the head of the AG Verhaltensforschung/ Ökologie in 1993, the DPZ took over financing the station in Kirindy (Fig. 2). This provided the basis for what is nowadays DPZ's largest field site where studies on eight primate species are conducted (red-fronted lemur, Eulemur rufifrons; Verreaux's sifaka Propithecus verreauxii; western fat-tailed dwarf lemur, Cheirogaleus medius; Madame Berthe's mouse lemur, Microcebus berthae; grey mouse lemur, Microcebus murinus; Coquerel's dwarf lemur, Mirza coquereli; red-tailed sportive lemur, Lepilemur ruficaudatus; fork-marked lemur, Phaner pallescens; e.g. Dammhahn and Kappeler, 2009; Kappeler and Fichtel, 2012).

Aside from Peru and Madagascar, students and scientists from the DPZ initiated field research in Brazil and Eritrea in the first half of the 1990s. Field research in Brazil began through a study on titi monkeys, Callicebus melanochir, in southern Bahia by Klaus-Heinrich Müller between 1991 and 1993 (e.g. Müller, 1995) at the Estação Experimental Lemos Maia of CEPLAC, the local cocoa growing authority in Una, Bahia. The project was continued by Stefanie Heiduck and Siglinde Schulze from 1993 to 1995 (e.g. Heiduck 1997, 2002). Until now, these have remained the only published studies on Southern Bahia titi monkeys.

Field research in Eritrea was initiated by Dietmar Zinner. First upon private initiative and then supported through a DFG grant, Zinner aimed at studying Hamadryas baboons, Papio hamadryas, under different ecological conditions, and at comparing yellow baboons, Papio anubis, and Hamadryas baboons under identical ecological conditions. First field stays in 1995 and from 1997-1998 were successful (Zinner and Torkler, 1996; Zinner et al., 2001a, b), but the emergence of an armed conflict between Eritrea and Ethiopia inhibited further work. Nevertheless, this initial field study on baboons was seminal for later pan-African research on baboon phylogeography (e.g. Hapke et al., 2001; Zinner et al., 2009).

\subsection{The consolidation of field research at DPZ}

For the further development and the consolidation of field research at DPZ, again recommendations from an evaluation were crucial. The committee that evaluated the AG Verhaltensforschung/Ökologie in 1996 recommended a conversion of this working group into a permanent department, Verhaltensforschung and Ökologie (Ethology and Ecology), renamed into Verhaltensökologe and Soziobiologie (Behavioral Ecology and Sociobiology) in 2004, under the directorship of Peter Kappeler who had come to DPZ in 1993 together with JUG and became head of the working group in 1997 after JUG was appointed as professor of animal ecology at the Universität Hamburg. This conversion took place 


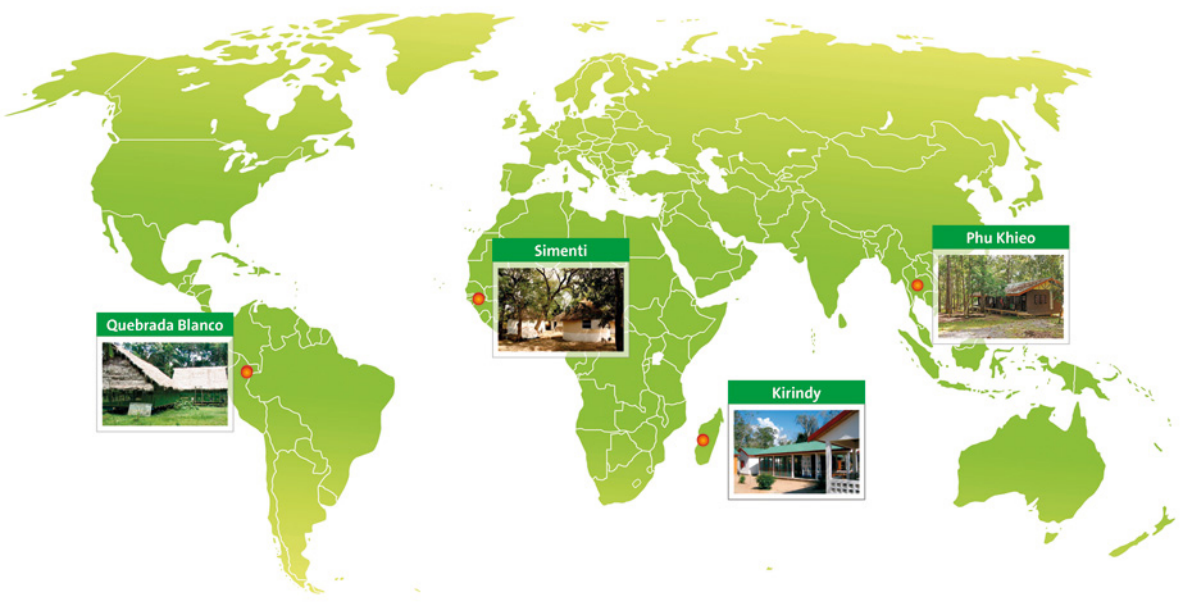

Figure 3. DPZ is unique, as it runs running field research sites in all major areas of primate distribution (map created by Heike Klensang. Source: Deutsches Primatenzentrum GmbH).

in 1998 and had several implications. First, it gave planning security for the two field stations (Madagascar, Peru). Second, planning security allowed for the initiation of long-term projects which are essential in primate field research (Kappeler and Watts, 2012). Third, planning security also allowed for establishing co-operations with other DPZ departments (Primate Genetics, Reproductive Biology) which expanded the range of research questions through the application of non-invasive methods for genetic and hormonal analyses established in these departments.

\subsection{Expansion of DPZ field research}

Field research did not remain confined to the department Behavioral Ecology and Sociobiology, but other departments and groups from DPZ's Organismic Primatology section joined in. Further field sites were established, thus expanding the geographic range of DPZ's research activities.

In 2002, the Department of Reproductive Biology (head: Keith Hodges) initiated field research on several primate species on Siberut Island (Indonesia) which continued until the end of 2013 (e.g. Hadi et al., 2012; Richter et al., 2013; Walter et al., 2008). The same department, through a junior research group (Antje Engelhardt), started research on crested macaques at Tangkoko on Sulawesi Island (e.g. Duboscq et al., 2013; Neumann et al., 2010).

The Department of Cognitive Ethology (head: Julia Fischer) initiated field research on Guinea baboons at Simenti in Senegal in 2007 (e.g. Maciej et al., 2013; Kopp et al., 2015).

Finally, in 2015 through an agreement between DPZ and the Universität Göttingen, field research was further expanded by taking over the research site at the Phu Khieo Wildlife Sanctuary in Thailand run by Julia Ostner and Oliver Schülke, Universität Göttingen. The field site at Phu Khieo Wildlife Sanctuary was originally established by An- dreas Koenig and Carola Borries, Stony Brook University, for their project on Phayre's langurs. In 2005 Julia Ostner and Oliver Schülke joined them and initiated the Assamese Macaque Project at Phu Khieo Wildlife Sanctury (e.g. Schülke et al., 2010; Ostner et al., 2013).

Apart from research at DPZ's field sites, many other projects have been run and are running in other areas, mostly in collaboration with international institutions, e.g. on snubnosed monkeys in China (Yang et al., 2009), white-handed gibbons in Thailand (Barelli et al., 2013), spider monkeys in Colombia (Rimbach et al., 2013) or mandrills in Gabon (Brockmeyer et al., 2015).

\section{Closing remarks}

Although not part of the original plans for a primate centre in Germany, field research on primate behaviour and ecology has become established at DPZ and is now one of its strongholds, both in terms of scientific output and public interest. The DPZ is unique amongst primate centres worldwide, as it runs four field research sites in all major regions of primate distribution - Africa, Asia, Madagascar and South America (Fig. 3) - and supporting long-term studies. This would have not been possible without the interest and enormous support that DPZ's founding director, Prof. Dr. HansJürg Kuhn, provided to field research projects and to the establishment of field sites. This created a momentum that resulted in the diversity of field research now conducted at DPZ.

Acknowledgements. First of all, we are deeply indebted to HansJürg Kuhn for his interest, support and encouragement. We should also like to thank Michael Casimir, Carsten Niemitz and HansJörg Schlichte for sharing their personal history of field research; Inge Weber for information on the first field project by Chris- 
tian Vogel (who died in 1994). We are also grateful to three reviewers who provided critical comments and helpful suggestions on the manuscript. E. W. Heymann also thanks the colleagues from the Peruvian primate centre in Iquitos, particularly the late Jaime Moro Sommo, for support. J. U. Ganzhorn is grateful to our colleagues from Madagascar who are as helpful to a students as they continue to be to "grown-up" colleagues.

Much of what has been achieved with DPZ's field research projects is due to the efforts of students; they are too many to name them here, but we are grateful to all of them. Finally, without the dedicated work of and the support by local field assistants, research on wild primates would not be possible at all. Again, they are too many to name them here, but we owe them many, many thanks.

Edited by: E. Fuchs

Reviewed by: V. Sommer, J. Ostner, and one anonymous referee

\section{References}

Barelli, C., Matsudaira, K., Wolf, T., Roos, C., Heistermann, M., Hodges, J.K., Ishida, T., Malaivijitnond, S., and Reichard, U.: Extra-pair paternity confirmed in wild white-handed gibbons, Am. J. Primatol., 75, 1185-1195, 2013.

Bartecki, U. and Heymann, E. W.: Sightings of red uakaris, Cacajao calvus rubicundus, at the Río Blanco, Peruvian Amazonia, Primate Conserv., 8, 34-36, 1987.

Bartecki, U. and Heymann, E. W.: Field observations of scentmarking behaviour in saddle-back tamarins, Saguinus fuscicollis (Callitrichidae, Primates), J. Zool., Lond., 220, 87-99, 1990.

Bartecki U., Heymann, E. W., Bodmer, R. E., Moya, L., and Fang, T.: Diagnóstico situacional de la zona de estudios quebrada Blanco en el río Tahuayo y propuesta para el establecimiento de una reserva nacional, Report to the Proyecto Peruano de Primatología and Ministerio de Agricultura, 1986.

Borries, C.: Patterns of grandmaternal behaviour in free-ranging Hanuman langurs (Presbytis entellus), Hum. Evol., 3, 239-260, 1988.

Brockmeyer, T., Kappeler, P. M., Willaume, E. Benoit, L., Mboumba, S., and Charpentier, M. J. E.: Social organization and space use of a wild mandrill (Mandrillus sphinx) group, Am. J. Primatol., published online, doi:10.1002/ajp.22439, 2015.

Carpenter, C. R.: A field study of the behavior and social relations of howling monkeys (Alouatta palliata), Comp. Psychol. Monogr., 10, 1-168, 1934.

Carpenter, C. R.: Behavior of red spider monkeys in Panama, J. Mamm., 16, 171-180, 1935.

Casimir, M. J.: Some data on the systematic position of the eastern gorilla population of the Mt. Kahuzi region (Republique du Zaire), Z. Morphol. Anthropol., 66, 188-201, 1974.

Casimir, M. J.: Feeding ecology and nutrition of an eastern gorilla group in the Mt. Kahuzi region (Republique du Zaire), Folia Primatol., 24, 81-136, 1975.

Casimir, M. J.: An analysis of gorilla nesting sites of the Mt. Kahuzi region (Zaire), Folia Primatol., 32, 290-308, 1979.

Casimir, M. J. and Butenandt, E.: Migration and core area shifting in relation to some ecological factors in a mountain gorilla group (Gorilla gorilla beringei) in the Mt. Kahuzi region (Republique du Zaire), Z. Tierpsychol., 33, 514-522, 1973.
Castro Coronado, N. R.: Behavioral ecology of two coexisting tamarin species (Saguinus fuscicollis nigrifrons and Saguinus mystax mystax, Callitrichidae, Primates) in Amazonian Peru, PhD dissertation, Washington University, St. Louis, 1991.

Chaoui, N. J.: Mit Messzirkel und Schrotflinte. Das primatologische Werk von Adolph Hans Schultz (1891-1976), Basilisken-Presse, Marburg, 2004.

Dammhahn, M. and Kappeler, P. M.: Females go where the food is: does the socio-ecological model explain variation in social organisation of solitary foragers?, Behav. Ecol. Sociobiol., 63, 939-952, 2009.

DeVore, I.: Preface, in: Primate behavior. Field studies of monkeys and apes, edited by: DeVore, I., Holt, Rinehart and Winston, New York, vii-x, 1965a.

DeVore, I.: Primate behavior. Field studies of monkeys and apes, Holt, Rinehart and Winston, New York, 1965b.

Duboscq, J., Micheletta, J., Agil, M., Hodges, J. K., Thierry, B., and Engelhardt, A.: Social tolerance in wild female crested macaques (Macaca nigra) in Tangkoko-Batuangus Nature Reserve, Sulawesi, Indonesia, Am. J. Primatol., 75, 361-375, 2013.

Engelhardt, A., Pfeifer, J. B., Heistermann, M., Niemitz, C., Van Hooff, J. A. R. A. M., and Hodges, J. K.: Assessment of female reproductive status by male longtailed macaques, Macaca fascicularis, under natural conditions, Anim. Behav., 67, 915-924, 2004.

Engelhardt, A., Heistermann, M., Hodges, J. K., Nürnberg, P., and Niemitz, C.: Determinants of male reproductive success in wild long-tailed macaques (Macaca fascicularis) - male monopolisation, female mate choice or post-copulatory mechanisms?, Behav. Ecol. Sciobiol., 59, 740-752, 2006.

Ganzhorn, J. U.: A possible role of plantations for primate conservation in Madagascar, Am. J. Primatol., 12, 205-215, 1987.

Ganzhorn, J. U.: Niche separation of seven lemur species in the eastern rainforest of Madagascar, Oecologia, 79, 279-286, 1989.

Ganzhorn, J. U.: Forstprojekt im Trockenwald Madagaskars, Biologie in unserer Zeit, 21, 293-297, 1991.

Ganzhorn, J. U., Abraham, J. P., and Rakotomalala, M.: Some aspects of the natural history and food selection of Avahi laniger laniger, Primates, 26, 452-463, 1985.

Ganzhorn, J. U., Ganzhorn, A. W., Abraham, J. P., Andriamanarivo, L., and Ramananjatovo, A.: The impact of selective logging on forest structure and tenrec populations in western Madagascar, Oecologia, 84, 126-133, 1990.

Hadi, S., Ziegler, T., Waltert, M., Syamsuri, F., Mühlenberg, M., and Hodges, J. K.: Habitat use and trophic niche overlap of two sympatric colobines, Presbytis potenziani and Simias concolor, on Siberut Island, Indonesia, Int. J. Primatol., 33, 218-232, 2012.

Hapke, A., Zinner, D., and Zischler, H.: Mitochondrial DNA variation in Eritrean hamadryas baboons (Papio hamadryas hamadryas): Life history influences population genetic structure, Behav. Ecol. Sociobiol., 50, 483-492, 2001.

Harrisson, B.: A study of orang-utan behaviour in semi-wild state, 1956-1960, Sarawak Mus. J., 9, 422-447, 1960.

Harrisson, B.: The immediate problem of the orang-utan, Oryx, 6, 128-130, 1961.

Harrisson, B.: Getting to know about Tarsius, Malay. Nat. J., 16, 97-204, 1963. 
Heiduck, S.: Food choice in masked titi monkeys (Callicebus personatus melanochir): selectivity or opportunism?, Int. J. Primatol., 18, 487-502, 1997.

Heiduck, S.: The use of disturbed and undisturbed forest by masked titi monkeys Callicebus personatus melanochir is proportional to food availability, Oryx, 36, 133-139, 2002.

Heymann, E. W.: Sex differences in olfactory communication in a wild primate, Saguinus mystax (Callitrichinae), Behav. Ecol. Sociobiol., 43, 37-45, 1998.

Heymann, E. W.: Spatial patterns of scent marking in wild moustached tamarins, Saguinus mystax: no evidence for a territorial function, Anim. Behav., 60, 723-730, 2000.

Hofer, H., Schultz, A. H., and Starck, D.: Primatologia - Handbuch der Primatenkunde. I. Systematik, Phylogenie, Ontogenie, S Karger, Basel, 1956.

Jay, P. C.: Primates. Studies in adaptation and variability, Holt, Rinehart and Winston, New York, 1968.

Kappeler, P. M. and Fichtel, C.: A 15-year perspective on the social organization and life history of sifaka in Kirindy forest, in: LongTerm Field Studies of Primates, edited by: Kappeler, P. M. and Watts, D. P., Springer, Heidelberg, 21-45, 2012.

Kappeler, P. M. and Watts, D. P.: Long-term field studies of primates, Springer, Heidelberg, 2012.

Koenig, A., Borries, C., Chalise, M. K., and Winkler, P.: Ecology, nutrition, and timing of reproductive events in an Asian primate, the Hanuman langur (Presbytis entellus), J. Zool. Lond., 243, 215-235, 1997.

Kopp, G. H., Fischer, J., Patzelt, A., Roos, C., and Zinner, D.: Population genetic insights into the social organization of Guinea baboons (Papio papio): evidence for female-biased dispersal, Am. J. Primatol., 77, 878-889, 2015.

Krieg, H.: Biologische Reisestudien in Südamerika. XVI. Die Affen des Gran Chaco und seiner Grenzgebiete, Z. Morph. Ökol. Tiere, 18, 760-785, 1930.

Kuhn, H.-J.: A provisional checklist of the mammals of Liberia. (With notes on the status and distribution of some species), Senckenbergiana Biol., 46, 321-340, 1965.

Kuhn, H.-J.: Denkschrift zur Situation der Primatenforschung, Franz Steiner Verlag, Wiesbaden, 1970.

Kuhn, H.-J.: On the perineal organ of male Procolobus badius, J. Hum. Evol., 1, 371-378, 1972.

Kuhn, H.-J.: Bericht über eine Reise nach Iquitos, Peru, vom 12. bis 23. November 1980, unpublished report to the Deutsches Primatenzentrum, 1980.

Kummer, H.: Schwerpunkte soziobiologischer Freilandforschung an Primaten, Verh. Dtsch. Zool. Ges., 1975, 59-70, 1975.

Kunkel, P.: In Mobutus Diensten, epubli, Berlin, 2013.

Maciej, P., Patzelt, A., Ndao, I., Hammerschmidt, K., and Fischer, J.: Social monitoring in a multilevel society: a playback study with male Guinea baboons, Behav. Ecol. Sociobiol. 67, 61-68, 2013.

Matthews, A., Matthews, A., and Niemitz, C.: Preliminary report on the distribution of mandrills (Mandrillus sphinx) in southwestern Cameroon, Primate Rep., 50, 105-113, 1998.

Müller, K.-H.: Langzeitstudie zur Ökologie von schwarzköpfigen Springaffen (Callicebus personatus melanochir, Cebidae, Primates) im atlantischen Küstenregenwald Ostbrasiliens, Doctoral dissertation, Freie Universität Berlin, Aachen, Verlag Shaker, 1995.
Neumann, C., Assahad, G., Hammerschmidt, K., PerwitasariFarajallah, D., and Engelhardt, A.: Loud calls in male crested macaques, Macaca nigra: a signal of dominance in a tolerant species, Anim. Behav., 79, 187-193, 2010.

Niemitz, C.: Zur Biometrie der Gattung Tarsius Storr, 1780 (Tarsiiformes, Tarsiidae). Eine funktionsmorphologische Studie als Beitrag zur Systematik und Phylogenie der Koboldmakis unter Verwendung elektronischer Rechenmittel mit dem Versuch einer Synopse morphologischer und ethologischer Ergebnisse, Doctoral thesis, Justus-Liebig-Universität Giessen, Giessen, 1973.

Niemitz, C.: Biology of tarsiers, Gustav Fischer Verlag, Stuttgart, 1984.

Niemitz, C.: Progreditur ordinara saltando et retrorsum... Normally proceeds in a leaping fashion, and backwards..., Int. J. Primatol., 31, 941-957, 2010.

Niemitz, C., Nietsch, A., Warter, S., and Rumpler, Y.: Tarsius dianae: a new primate species from Central Sulawesi (Indonesia), Folia Primatol., 56, 105-116, 1991.

Nikolei, J. and Borries, C.: Sex differential behavior of immature Hanuman langurs (Presbytis entellus) in Ramnagar, South Nepal, Int. J. Primatol., 18, 415-437, 1997.

Nissen, H. W.: A field study of the chimpanzee, Comp. Psychol. Monogr., 8, 1-122, 1932.

Norconk, M. A.: Mechanisms promoting stability in mixed Saguinus mystax and S. fuscicollis troops, Am. J. Primatol., 21, 159170, 1990.

Ostner, J., Vigilant, L., Bhagavatula, J., Franz, M., and Schülke, O.: Stable heterosexual associations in a promiscuous primate, Anim. Behav., 86, 623-631, 2013.

Ramirez, M. M.: Feeding ecology and demography of the moustached tamarin Saguinus mystax in northeastern Peru, PhD Dissertation, City University of New York, New York, 1989.

Richter, C., Taufiq, A., Hodges, K., Ostner, J., and Schülke, O.: Ecology of an endemic primate species (Macaca siberu) on Siberut Island, Indonesia, Springer Plus, 2, 137, 2013.

Rimbach, R., Link, A., Heistermann, M., Gómez-Posada, C., Galvis, N., and Heymann, E. W.: Effects of logging, hunting, and forest fragment size on physiological stress levels of two sympatric ateline primates in Colombia, Conservation Physiology, 1, cot031, doi:10.1093/conphys/cot031, 2013.

Schlichte, H.-J.: Nahrungsverhalten von Diademmeerkatzen im Nationalpark Kahuzi-Biega, Kivuhochland, Zaire, Z. Säugetierk., 40, 193-214, 1975.

Schwibbe, M.: The German Primate Center - planning and realization of the institute, Primate Biol., 2, 13-19, doi:10.5194/pb-213-2015, 2015.

Schlichte, H.-J.: The ecology of two groups of blue monkeys, Cercopithecus mitis stuhlmanni, in an isolated habitat of poor vegetation, in: The ecology of arboreal folivores, edited by: Montgomery, G. G., Smithsonian Institution Press, Washington, 505517, 1978a.

Schlichte, H.-J.: A preliminary report on the habitat utilization of a group of howler monkeys (Alouatta villosa pigra) in the National Park of Tikal, Guatemala, in: The ecology of arboreal folivores, edited by: Montgomery, G. G., Smithsonian Institution Press, Washington, 551-559, 1978b.

Schülke, O., Bhagavatula, J., Vigilant, L., and Ostner, J.: Social bonds enhance reproductive success in male macaques, Curr. Biol., 20, 2207-2210, 2010. 
Sommer, V.: Infanticide among free-ranging langurs (Presbytis entellus) at Jodhpur (Rajasthan/India): recent observations and a reconsideration of hypotheses, Primates, 28, 163-197, 1987.

Vogel, C.: Über den phylogenetischen Wert von Mandibelmerkmalen bei höheren Primaten, Z. Morphol. Anthropol., 51, 275288, 1961.

Vogel, C.: Die Bedeutung der Primatenkunde für die Anthropologie, Naturw. Rundsch., 19, 415-421, 1966.

Vogel, C.: Bericht über eine Forschungsexpedition nach NordIndien, Anthropol. Anz., 31, 312-314, 1969a.

Vogel, C.: Funktionelle und phylogenetische Aspekte der Morphologie des Schädels höherer Primaten einschließlich der Hominiden, Z. Morphol. Anthropol., 60, 242-262, 1969 b.

Vogel, C.: Ökologie, Lebensweise und Sozialverhalten der Grauen Languren in verschiedenen Biotopen Indiens, Fortschr. Verhaltensforsch., 17, 1-160, 1977.

Walter, M., Abegg, C., Ziegler, T., Hadi, S., Priata, D., and Hodges, J. K.: Abundance and community structure of Mentawai primates in the Peleonan Forest, N Siberut, Indonesia, Oryx, 42, 375-379, 2008.

Washburn, S. L., Jay, P. C., and Lancaster, J. B.: Field studies of Old World monkeys and apes, Science, 150, 1541-1547, 1965.

Weber, I. and Vogel, C.: Social behavior in unisexual and bisexual langur groups, Homo, 21, 73-80, 1970.

Wikipedia: Área de Conservación Regional Comunal Tamshiyacu Tahuayo https://es.wikipedia.org/wiki/Área_de_conservación_regional_ Comunal_Tamshiyacu_Tahuayo, last access: 6 February 2015.
Winkler, P., Loch, H., and Vogel, C.: Life history of Hanuman langurs (Presbytis entellus). Reproductive parameters, infant mortality, and troop development, Folia Primatol., 43, 1-23, 1984.

Wissenschaftsrat: Stellungnahme zum Deutschen Primatenzentrum (DPZ) in Göttingen, in: Stellungnahmen zu biologischen Forschungseinrichtungen außerhalb der Hochschulen, edited by: Wissenschaftsrat, Bonn, 7-39, 1991.

Yang, M., Sun, D. Y., Zinner, D., and Roos, C.: Reproductive parameters in Guizhou snub-nosed monkeys (Rhinopithecus brelichi), Am. J. Primatol., 71, 266-270, 2009.

Zinner, D. and Torkler, F.: Hamadryas baboons Papio hamadryas in Eritrea, African Primates, 2, 65-67, 1996.

Zinner, D., Pelaez, F., and Torkler, F.: Group composition and adult sex-ration of hamadryas baboons (Papio hamadryas hamadryas) in central Eritrea, Int. J. Primatol., 22, 415-430, 2001 a.

Zinner, D., Pelaez, F., Torkler, F., and Berhane, D.: Primates of Eritrea - current distribution and habitat, African Primates, 5, 7-17, $2001 b$.

Zinner, D., Groeneveld, L., Keller, C., and Roos, C.: Mitochondrial phylogeography of baboons (Papio spp.) - indication for introgressive hybridization?, BMC Evol. Biol., 9, 83, doi:10.1186/1471-2148-9-83, 2009. 